\title{
Separating the Theological Sheep from the Philosophical Goats
}

\author{
Jonathan Curtis Rutledge \\ University of Notre Dame
}

\begin{abstract}
Andrew Torrance has recently argued that we can distinguish analytic theology from analytic philosophy of religion if we understand theology as, fundamentally, a scientific enterprise. However, this distinction holds only if philosophy of religion is not itself a science in the sense intended by Torrance. I argue that philosophy of religion is a science in this sense, and so, that Torrance cannot distinguish theology from philosophy of religion in the way suggested. Nevertheless, I offer two alternative routes to the distinction based on the nature of the respective objects of study in theology and philosophy of religion. Thus, I demonstrate that there is a coherent model available to Torrance which preserves the distinction he seeks.
\end{abstract}

Analytic theology, a research program following on the heels of the renaissance of analytic philosophy of religion, suffers from an ironic difficulty, namely, a seeming inability to lucidly define itself. ${ }^{1}$ Much of this concerns the definition of "analytic" in "analytic theology"; however, similar worries can be raised for the proper definition of "theology" in "analytic theology" as well. And these difficulties become especially apparent when one seeks to distinguish analytic theology from analytic philosophy of religion in a principled manner.

In this essay, I discuss one recent attempt (Torrance 2019) to distinguish analytic theology from analytic philosophy of religion by emphasizing the old and venerable practice of defining theology as "scientia ... [that is,] theology as an endeavor to understand a mind-independent object in a way that is true to the nature of that object" (ibid., 179). Moreover, since the reflections of this paper are relevant to the distinction between theology and philosophy of religion independent of their analytic

${ }^{1}$ For several attempts to define (or in some cases, describe or explicate) analytic theology, see Rea (2009); McCall (2015); Crisp (2011); Timpe (2015); Abraham (2009); Wood (2014); Rutledge (2019).

Journal of Analytic Theology, Vol. 9, Summer 2021

10.12978/jat.2021-1.3540-39434630

(C) 2021 Jonathan Curtis Rutledge • (C) 2021 Journal of Analytic Theology 
and non-analytic counterparts, I proceed without consciously attending to the distinctives of the analytic tradition. And importantly, my primary contention in this essay is not that we should reject a definition of theology as a science, but rather, that Torrance's approach to defining theology in this way requires emendation if it is to succeed in its goal of distinguishing theology from philosophy of religion.

I begin in $\S 1$ with a discussion of Torrance's definition of theology by means of an analogy with work in philosophy of language concerning essences and natural kinds. For it seems to me that if we are to understand theology as a science, it helps to begin by reflecting on what conditions need to be met in order for an academic enterprise to count as a science in the first place as well as how one might go about distinguishing between different sciences (e.g., as when one moves from practicing biology to astronomy). Following this, in $\S 2$, I offer suggestions concerning how contemporary philosophical practitioners think about the objects of their philosophical investigations (i.e., ways of thinking that demonstrate that Torrance's definition of theology as a science is insufficient, pending my suggested emendations, to distinguish theology from philosophy of religion). Then, in §3, I look at Torrance's suggestion that theology must include reference to God's historical revelation as a defining element if it is to legitimately distinguish itself from philosophy of religion. This recommendation requires some fine-tuning, however, insofar as it threatens to introduce contingent features of the actual world into the definition of theology. To avoid introducing contingency into the definition of theology, I suggest that a combination of reflection on the nature of revelation and further consideration of what is required to study a person such as God offers a better way forward for distinguishing theology from its merely philosophical counterpart. ${ }^{2}$ This resulting construal of theology as a science, however, leaves unaddressed a number of questions that are likely to give readers legitimate pause. In §4 I address some of these questions head on in the hopes of removing at least some of the obstacles one might encounter for giving the definition of theology as a science serious consideration.

\section{What Does it Mean for Something to be a Science?}

Let us begin, then, by thinking about what it means for a form of study to be a science. First, a couple of preliminary qualifications:

God is not a natural phenomenon in the way that the objects of science are seen to be natural phenomena. For instance, God doesn't fit into a test tube or submit Godself to empirical manipulation as, say, water does. So, the

\footnotetext{
2 I take God to be a person in the minimal sense that there is in the divine nature a single mind and will. See, for instance, Stump $(2018,418 \mathrm{fn} 38)$. Thus, by saying that God is a person in this sense I am not denying that God is three persons in whatever sense of "person" fits the conciliar Trinitarianism of traditional Christianity (e.g., subsistent relations).
} 
understanding of what makes a discipline part of the sciences does not require that its object be a part of the natural, created order.

Scientists are empiricists insofar as they take empirical investigation (via their senses) to fundamentally guide the inferences they make. This is not a naïve anti-rationalist position, but rather, a reasonable procedure given the nature of the typical objects of scientific study. God is not straightforwardly captured by the workings of our stereotypical five senses, but this does not prevent theology from being a science. For so long as we allow that the reality being investigated is mind-independent, this intuitively captures what is intended. ${ }^{3}$

So, for theology to count as a science, we need not presuppose that God belongs to the created order or that God can be studied using the main five human senses. But what more than this does it mean to say that something is a science? As an example, consider the discipline of hydrology.

If one were to define the field of hydrology, the most obvious place to begin is by talking via direct reference about the phenomenon at which hydrologists' observations are aimed; namely, water. So, suppose that you have two scientists, Quinn and Weston, who identify themselves as hydrologists. You ask Quinn to tell you about a sample of water she has studied for the past decade, and she tells you that it has the following properties: it is refreshing to drink, clear to the eye, and has the chemical structure $\mathrm{H}_{2} \mathrm{O}$. In other words, it is reasonable to conclude, assuming she is telling the truth, that Quinn is indeed a hydrologist. ${ }^{4}$

Suppose when you ask Weston to provide a similar description of his sample of water, he claims that it is, like Quinn's sample, clear to the eye and refreshing to drink, but unlike Quinn's sample of water, it has the chemical structure $\mathrm{C}_{2} \mathrm{H}_{5} \mathrm{OH}$. We then challenge him, saying, "You must be mistaken about something here. I thought you said you were a hydrologist! $\mathrm{C}_{2} \mathrm{H}_{5} \mathrm{OH}$ is ethanol, and there's no way that ethanol would be refreshing to drink! So, either you're an ethanologist or you've utterly misidentified the underlying chemical structure of your so-called water sample."

In this case, you are correct when you say that something is wrong with Weston's claims. Suppose he is correct about the chemical structure of his sample. In that case, he studies ethanol, not water. Indeed, this is true even if Weston sincerely believes that he has been studying water all along. And the reason is that if something being studied lacks properties which are essential to the natural kind under question,

\footnotetext{
3 These two qualifications are also made on Torrance $(2019,179-180)$. It is worth noting, alongside Torrance, that this understanding of theology as scientia is not novel, but rather, was the understanding of theology advanced by such luminaries as "Thomas Aquinas [Summa Theologiae I, q. 1, a. 2], Bonaventure [In I Sent., pro., q. 2, ad. 4], Frances Turretin [Institutio of theologiae elencticae (Geneva, 1679-1685; new ed., Edinburgh, 1847), 1.5.2-4], Karl Barth [C. D. 1.1, 190-194, edited by G.W. Bromily and T.F. Torrance], T.F. Torrance [Theological Science (Edinburgh: T\&T Clark, 1996)], and John Webster [“What Makes Theology Theological?" Journal of Analytic Theology 3 (2015): 1728]" (Torrance 2019, 180; bracketed citations added).

${ }^{4}$ For the classic discussions of water as $\mathrm{H}_{2} \mathrm{O}$ or XYZ that inspired my thinking here, see (i) Putnam (1973) and (ii) Putnam (1975).
} 
such as an underlying chemical structure, then that thing necessarily fails to belong to the relevant natural kind. In other words, it is impossible for anything to belong to a kind while lacking essential properties of that kind. ${ }^{5}$

Suppose, on the other hand, that Weston has gotten the chemical structure of his sample right, and moreover, suppose Weston has made no mistakes about the observable physical properties of his sample of ethanol either. That is, suppose that Weston is correct that this sample of ethanol is (perhaps shockingly) refreshing to drink despite your protests. In such a case, what is going on?

Here is a basic explanation. ${ }^{6}$ Chemical structures are essential to things like water, but we do not identify water in the world by looking to see if the apparent water we have come across (e.g., perhaps while hiking around the Great Lakes) is $\mathrm{H}_{2} \mathrm{O}$. Rather, we appeal to superficial properties such as its refreshing quality and clearness to the eye to refer to it. So long as those superficial properties do not strongly supervene on the underlying chemical structure (i.e., so long as the superficial properties of water can come apart from the chemical structure of water in principle), we might misidentify a substance with all the superficial properties of water as water despite the fact that it is some other substance (e.g., ethanol). If Weston still thinks he is a hydrologist after our challenge, then, it is because he has mistakenly privileged such superficial properties as the determinants of what counts as water rather than the underlying chemical structure. So, what does all of this have to do with theology?

Take two self-identified theologians, Katherine and Abigail, and suppose that they claim to be theologians in virtue of the fact that God is the mind-independent subject of their study. Then on the view that theology is a science, what is it that determines whether or not they really are theologians? The answer is that they are theologians only if their claims to study God are true. Or to offer a slightly different claim, they are theologians only if the subject of their study in fact has all the essential properties of God. ${ }^{7}$ In other words, whether or not they are theologians has little to do with whether they merely think they are theologians. It matters whether they are right in the same way that it mattered whether Weston was right that his sample was water. Weston was wrong, so he was not a hydrologist. Similarly, if Katherine or Abigail are wrong, then they are not theologians.

So, recall that the foregoing is merely an explication of Torrance's notion of a science. Following him, then, I have suggested that we understand someone to be a theologian only if the subject of their study is God. Such a claim is consistent with

\footnotetext{
${ }^{5}$ And presumably, this is a point with which theologians can get on board since it motivates a number of theological responses to heretical views, such as Gregory of Nazianzus' response in Epistle 101 to one form of Apollinarianism.

6 This sort of explanation is available in many places, but for a particularly lucid presentation, see Zagzebski (2018).

7 The talk of properties and "essential" as opposed to accidental properties is a bit loose. Such talk can be translated into more careful claims regarding God's attributes should someone (e.g., such as the present author) desire to maintain a doctrine of divine simplicity in line with the Christian tradition. See Crisp $(2019,53-75)$ for a recent analytic defense of a version of divine simplicity.
} 
disagreement between Katherine and Abigail concerning God's nature. Perhaps, for instance, Katherine is a Trinitarian while Abigail is a Unitarian. This is a disagreement about God's essential nature, but it need not be explained by Katherine and Abigail studying different objects. Instead, one of them might simply be mistaken regarding the properties of the object of their study, just as Weston in the case above could have been studying water but simply mistaken about the underlying chemical structure of his sample.

Suppose, however, that there is a third theologian, called Toni, and suppose Toni shares all the same theological opinions held by Katherine. But suppose further that, despite Toni's belief that he is studying precisely the same object as Katherine, he has formed these beliefs because he thinks Katherine is wickedly smart and that he is most likely to succeed in life by believing whatever Katherine believes. ${ }^{8}$ A proper subset of the beliefs Katherine holds to are theological, and thus, by a sort of accident Toni acquires a huge number of beliefs that appear theologically correct (i.e., given that Katherine's beliefs are indeed true).

Is Toni a theologian (in the scientific sense) as described? Whether or not he is depends on what it means to be properly related to the object of theological study. As the case is described, however, the object of Toni's study is not obviously God, strictly speaking, since he has never directed his attention to God. Rather, he has directed his attention to Katherine's beliefs about God. As a result, and insofar as this description of Toni is apt, something might be missing from Toni's relationship to the object of theology. For if we cannot rule out the possibility that Toni can study Katherine's beliefs about God without simultaneously studying God in the way that Katherine does, then Toni's attempt to practice theology might be deficient in a way that precludes him from counting as a true theologian.

Now, you, reader, are likely to have objections to the points just made in the previous paragraph concerning Toni. This is good, for what I have said so far is by itself insufficient to explain how Toni could fail to be studying God when adopting Katherine's beliefs about God. I assure you that I have more to say, but allow me to bracket that discussion off until $\S 3$. For at this point, enough has been said to illuminate what it means for theology to be a science in the sense intended by Torrance. Let us turn, then, to Torrance's argument that in virtue of the mindindependence of theology's object, we can distinguish theology from (mere) philosophy of religion.

\section{Should Philosophy Count as a Science?}

Recall as discussed in the introduction that Torrance claims that the definition of theology as a science is sufficient to distinguish theology from philosophy of religion. If that is correct, then being a science in the sense described above cannot apply to

\footnotetext{
8 This way of speaking that involves trusting that one can do better by taking on the beliefs of someone else is articulated in Zagzebski (2012).
} 
philosophy of religion. In this section, I argue on the contrary that philosophy (and so, philosophy of religion) does count as a science as described above, or at the very least, that philosophy's practitioners typically assume that it counts as such. Consequently, defining theology as a science alone fails to sufficiently distinguish theology from philosophy of religion. here:

Let us begin with Torrance's own statement of the position we are targeting

I shall argue that the uniqueness of analytic theology lies in what I shall refer to as a commitment to being "scientific" (179).

... there are at least two ways to think about what we call "theology": one that is more generic and one that is more concrete-with the latter being distinguished by its scientific character. What I shall also note is that the more generic understanding of analytic theology is not so easily distinguished from philosophy of religion ... If these two versions [of analytic theology] are confused, then the reality of GATRG [i.e., God and all things in relation to God] (the object of scientific theology) risks being reduced to a mind-dependent object of philosophy of religion - to human thoughts about GATRG ... (180).

As is evident in the above quotation, the qualifier of theology as "analytic" is inessential for Torrance's purposes. It is theology, whether analytic or non-analytic, that admits of a scientific understanding, and it is in virtue of this scientific understanding that Torrance thinks it can be distinguished from philosophy of religion.

But notice that for Torrance, if theology is not understood as a science, then it risks reduction to the "mind-dependent object of philosophy of religion." This appeal to mind-dependence for the objects of philosophy reveals, I think, a fundamental misunderstanding of what philosophy is, or at least the understanding of philosophy that philosophers of religion typically assume.

What is it for something to be mind-dependent? As a first pass, one might think $x$ is mind-dependent if, and only if, there is no possible world at which $x$ exists and no mind exists. Such a definition of mind-dependence fails here, however, since God exists necessarily, has a mind, and not a single quark can exist in a world without God (from which it follows that not a single quark can exist in a world without a mind).

Perhaps we could rework our definition of mind-dependence in the following way: $x$ is mind-dependent if, and only if, $x$ only has existence insofar as $x$ exists in a non-God mind. If we assume that familiar forms of idealism are false, then this would preclude the worry of quarks, for instance, counting as mind-dependent objects, and so, this definition improves upon the previous one. ${ }^{9}$ Indeed, this seems to be more or less what Torrance intends in his discussion, and thus, we can assume it is the relevant

\footnotetext{
${ }^{9}$ This is not to say that pursuing the definition of theology as distinct from philosophy of religion from a Christian idealist perspective is an unworthy pursuit.
} 
notion in what follows. ${ }^{10}$ But the problem is that on the assumption that this notion of mind-dependence is right, then it is implausible to think that the objects of philosophical inquiry would count as mind-dependent. To see why, let us begin with a bad (though enlightening) argument for the claim that philosophy is not a science.

Suppose that philosophy can be done from the armchair. ${ }^{11}$ Then this might lead us to think philosophy clearly is not a science. After all, someone might think, scientists study objects out in the world, but no one is attending to objects out in the world from their armchair. Despite the naturalness of such a thought, it is mistaken. Indeed, given the definition of a science as a study of mind-independent objects, there is reason to think being in an armchair precludes philosophy from counting as a science only if one cannot attend to mind-independent objects from the armchair. Or what is more, thinking from the armchair precludes one from attending to mindindependent objects only if all mind-independent objects are "out in the world" in the same sense. Of course, God is not some object "out in the world" in this sense, and so, if this objection worked against defining philosophy as a science, it would also rule out defining theology as a science. But even if we set this aside, it is just absurd to think all mind-independent objects other than God are "out in the world."

Consider the number 8 . The number 8 exists. ${ }^{12}$ Indeed, the number 8 is the answer to the question of how many planets are in our solar system. But the number 8 does not exist "out in the world." It is not the sort of thing that can swim or be spatially located. But it is also not the sort of thing that exists only in a non-God mind. ${ }^{13}$ Suppose God had decided to actualize a different possible world that appeared exactly like ours except that all creatures that appeared to have minds in that world were, contrary to expectation, mindless zombies. ${ }^{14}$ The number 8 would exist in that world, but no non-God mind would exist. It follows, then, that not all mind-independent objects are out 'in the world' in the sense assumed by the objector to conceiving of philosophy as a science along these lines.

\footnotetext{
${ }^{10}$ Moreover, Torrance has confirmed as much in personal correspondence.

${ }^{11}$ I doubt that we should think this, but we need not assume anything other than the stereotypical Cartesian picture of philosophy in the armchair to see why philosophy is not a mind-dependent discipline. See Williamson (2007) for an excellent discussion of how one ought to think about the discipline of philosophy.

12 Of course, the existence of the number 8 is itself controversial (see, e.g., Fine (2005)). It's a useful example but not essential for the point. What examples suffice will, of course, depend on one's ontology. Thus, given someone's preferred ontology, we can find an alternative example by locating something in their ontology to which philosophers might direct their philosophical attention but which clearly exists whether or not any minds, which are not God, exist. Many philosophers will be happy to admit propositions or concepts into their ontology, which, as I discuss later, would be sufficiently mind-independent. Indeed, if one is a semantic or content externalist, then one would be committed to meanings that are at least partly mind-independent. This sort of commitment would suffice, I think, to demonstrate that philosophy counts as a science in Torrance's sense as well. 13 I do not intend 'mind' to refer to some ontologically univocal part of God. Whatever the unproblematic analogical understanding of the use of 'mind' here would be, that is what I intend. ${ }^{14}$ For discussion of these phenomenologically deficient zombies and their relation to physicalism, see Chalmers (1996).
} 
But now, if we reflect on stereotypical construals of what philosophy is in the academy, it centrally involves some form of conceptual analysis. What are the objects of study when engaged in conceptual analysis? The answer is straightforward enough; they are concepts. Now, concepts also can be combined by way of various logical operators to constitute propositions, and so, conceptual analysis does not only concern concepts but also propositions. So, among the objects of philosophical study are concepts and propositions..$^{15}$

But what sort of thing is a concept and what sort of thing is a proposition? These are convoluted questions, and I do not have space to discuss them in great detail here, so some plausible stipulative definitions will have to suffice. A concept is a mental representation that can have its meaning either demonstratively (e.g., that is blue) or by description (e.g., chairs are complex artifacts designed for the purpose of providing seating). A proposition, on the other hand, is an abstract bearer of truthvalue which is about something (i.e., it is, like concepts, representational). ${ }^{16}$

Must we think of concepts and propositions as mind-dependent? Typically, contemporary philosophers strongly resist the idea that the meanings of concepts and propositions are reducible to what is in the head, and so, concepts and propositions must have at least some degree of mind-independence. The well-known discussion by Hilary Putnam of water on Twin Earth offers us a case in point. ${ }^{17}$ Suppose that a scientist on Twin Earth points to a clear body of liquid and says, "That's water!" What does the word "water" refer to in his utterance? Well, on Twin Earth the clear bodies of liquid that appear indistinguishable from Earth's water at the macrolevel have the chemical structure XYZ. So, the use of "water" by the Twin Earth denizen refers to the substance with the chemical structure XYZ. But then, as Putnam claimed, were someone from Twin Earth brought to our Earth, their concept of water would be determined on the basis of their prior interaction with the Twin Earth environment. And so, if they were to point at a clear body of liquid and say on Earth, "That's water!" they would have made a mistake. What they mean by water is the Twin Earth stuff; namely, XYZ. But what we mean by "water" on Earth is something fundamentally different; namely, $\mathrm{H}_{2} \mathrm{O}$. Thus, the meaning and reference of at least some concepts (e.g., proper names and natural kind terms) is a function not only of one's mind but also the external world. If so, then there is a clear degree of mindindependence involved in conceptual analysis.

Indeed, the fact that philosophers engage in argument at all illustrates that they as philosophical practitioners assume there is something independent of their minds about which to argue. For instance, epistemologists spend much time (on my view far too much time) arguing about the definition of knowledge. Is knowledge justified true belief? Is it reliable true belief? Is it unanalyzable? ${ }^{18}$ Or for an example

\footnotetext{
15 What I do not say here is that concepts and propositions are the only objects of philosophical study, lest anyone think I am reducing philosophy to mere conceptual analysis.

${ }^{16}$ For concepts, see Margolis and Laurence (2011). For propositions, see Merricks (2015) or King,

Soames, and Speaks (2014).

17 Cf. Putnam $(1973,1975)$.

${ }^{18}$ Cf. Feldman (2003); Goldman (1979); Williamson (2000).
} 
from metaphysics, philosophers often argue about whether or not personal identity is a function of biological persistence conditions, psychological continuity, or perhaps the narratives we tell about ourselves. ${ }^{19}$ Such arguments make little sense if these philosophers do not take themselves to be arguing about a shared concept (i.e., respectively, knowledge or personal identity) the meaning of which is not reducible to their own descriptions of it. Thus, philosophy as a general enterprise seems quite naturally to be involved in the investigation of mind-independent objects, even if those objects are not always accessible via traditional empirical methods.

So, philosophy as a discipline is defined by investigating mind-independent objects. The objects of philosophy are also not amenable to being tested by traditional empirical methods, but insofar as this does not preclude theology from counting as a science, neither should it preclude philosophy from so counting. Thus, the above reflections are, I think, sufficient to demonstrate that philosophy is a science in the sense employed by Torrance, and as a result, it cannot be distinguished from theology by appeal to this feature.

\section{Historical Contingency or the Existential Requirement of Revelation}

So, theology and philosophy are both sciences, and the concept of God can, and often does, serve as an object of philosophical inquiry. Should this fact lead us to reject any clear distinction between theology and mere philosophy of religion? ${ }^{20}$ It should not, and the reason has to do with one of two things. First, it depends on whether or not someone employing the concept "God" employs a concept that is appropriately tied to God (via the right sort of causal history). And second, it depends on whether having access to the sorts of propositional contents found in theology (e.g., that God is triune or that Jesus was the messiah) is sufficient to study God. ${ }^{21}$ If either of these states of affairs obtains (i.e., either some philosophers of religion fail to refer to God when using "God" or propositional knowledge concerning God is an insufficient basis for studying God) then it will be possible to clearly distinguish the object of theology from that of philosophy of religion in such a way that they plainly fit as separate disciplines.

Recall the Twin Earth example from above. The denizen of Twin Earth had a concept that went by the name "water," and the concept admitted of mindindependent elements (i.e., the meaning of water was not all and only in his head).

${ }^{19}$ Cf. Olson (1997); Shoemaker (2011); Schechtman (1996).

${ }^{20}$ Insofar as philosophy of religion involves drawing inferences from propositional contents about God, then clearly theology involves the practice of philosophy of religion. This is why I emphasize here, as I have on occasion elsewhere, that the distinction is really between theology and mere philosophy of religion. Henceforth, "mere" should be understood to qualify philosophy of religion when it is contrasted with theology.

${ }^{21}$ In this section, then, I assume that $x^{\prime}$ s studying God entails $x$ has the ability to refer to God. The reverse implication, however, does not immediately hold, and I offer an argument for this in what follows. 
Nevertheless, when he employed that Twin Earth concept on our Earth, his referring ability was interrupted, and the reason was that the concept he employed had been fixed by another object that was necessarily not- $\mathrm{H}_{2} \mathrm{O}$. In other words, whether or not one can successfully refer to something, G, depends on how the concept by which one intends to refer to that thing, g, was acquired (i.e., roughly, its causal history). ${ }^{22}$

Now, remember this condition of successful reference. We will return to it, but first, we need to turn our attention to a shift in Torrance's discussion of theology where he moves from defining theology (i.e., a general project) to a Kierkegaardian emphasis on the historical contingency of Christian revelation and its importance in the actual world for scientific theology (Torrance 190-192). Importantly, at this point in Torrance's argument, he takes himself to have successfully distinguished theology from philosophy of religion by means of defining theology as a science. We have seen he is mistaken in thinking that this is sufficient for achieving his aim, but in what follows, I suggest that there are resources in our Twin Earth discussion for supplementing Torrance's account. Indeed, what is needed in addition to defining theology as a science is further reflection on the essential features of the object of theology and how those features ought to play either into the acquisition of the concept of God for a theologian or in the kind of knowledge essential to the study of God. Let us begin with the former possibility concerning one's ability to acquire the concept of God via direct reference.

Suppose that the God of the Christian tradition exists. ${ }^{23}$ There are many things one can say about the Christian God: God is a Trinity, God is transcendent of any creation there may be, and God came as a human to reconcile the (actual) world to Godself. Of the range of properties referred to by these various locutions, the former two are essential to God and the final one is contingent.

Now, someone might be tempted to say, if we are really to practice theology in the scientific sense, we simply must take God's self-revelation seriously. And that means that to do theology we must think of God in terms of the Incarnation and redemption of the world, for redemption is part and parcel of God's self-revelation. Torrance would certainly affirm this sentiment, but what might it mean to take God's self-revelation seriously if one is to practice theology?

There are at least two ways to understand what someone might mean in saying the above. The first way is to understand theology as defined by the historically contingent events in which God is an especially significant player. Such an understanding is hopeless, however. Insofar as there are any possible worlds in which God chooses to reveal Godself differently than God actually has, then were the contingent facts about God to play into a definition of theology, the definition of theology would be different across possible worlds. But a definition of theology is

\footnotetext{
${ }^{22}$ There is much more to the story, of course. For instance, the reference might shift, as plausibly "Santa Claus" historically has (cf. Bogardus and Urban $(2017,180)$ ) for this example in a related context). For an early \& indispensable defense of the causal theory of reference, see Kripke (1972).

${ }^{23}$ And allow me to note that, in Torrancian fashion, this supposition is true.
} 
adequate only if it remains constant across possible worlds. Thus, no definition which incorporates historically contingent elements can be correct.

The second way to understand what it means to say that theology requires us to take seriously the Incarnation and redemption of the world is this: in any world where God creates, there is revelation, for any created thing derives its being from God's own being. Thus, any created thing will bear an imprint revealing something of divinity. Consequently, to engage in theology well, all theologians, no matter their location in terms of modal space (i.e., no matter what their particular possible world looks like), ought to attend to the specific contents of God's self-revelation. In the actual world, the contents of that self-revelation contingently include the claims that God assumed human flesh and reconciled the world to himself by the blood of his cross. Thus, if one wants to engage in theology well in the actual world, one must "bind themselves in prayer to the one mediator (1 Tim 2:5), Jesus Christ" and draw one's theological inspiration from the Holy Spirit who imparts divine wisdom (Torrance 2019, 192). That is, good theologians account for the economic activity of the divine persons as it takes place in their own contingent historical contexts.

Clearly, the most charitable interpretation of such a claim, then, is this latter option according to which what is essential to the practice of theology is that it can succeed only if one attends to revelation (although, crucially, no particular historical revelation belongs to the definition). Notice, however, that if one identifies the person of God with God's revelation (i.e., in the way that someone like Barth does) and theology is the study of the person of God, then not only does good theology require attending to God's self-revelation but all theology requires one to attend to God's selfrevelation. ${ }^{24}$ If one incorporates this understanding of revelation into the scientific definition of theology, then one can carve out a distinction between theology and philosophy of religion in the following two ways.

Unlike the object of hydrology, theology's object is a subject (i.e., a person). And this is important since persons are not easily manipulated or studied the way samples of water might be. To discover the nature of water, one puts it under the microscope, observes how it reacts with other substances, etc. But if one is to come to know a person, one must recognize that the person is not inert in the way a substance is. In particular, a person can choose to withhold personal presence from another if, for some reason, they do not wish to be known by that person at that time. ${ }^{25}$ Thus, given that the subject of theology is a person, acquiring the ability to represent that person (even minimally by mere ostension) becomes tricky.

Earlier I said that whether or not one can successfully refer to something, G, depends on how the concept by which one intends to refer to that thing, g, was acquired (i.e., its causal history). Consider first how this works when working with

\footnotetext{
${ }^{24}$ According to this Barthian way of construing scripture, scripture is revelation in a derivative sense. ${ }^{25}$ For the notion of personal presence operative here, see Stump $(2018$, ch. 4). As a brief explanation, suppose you sit down to dinner with your family and your son pulls out his cellphone to check Facebook. You immediately say, "Henry, put your cellphone away. You need to be present with us during dinner." That is the sense of presence picked out by personal presence, which involves mutual awareness of and shared attention with each other.
} 
hydrologists from Earth and Twin Earth. On Twin Earth, twin-water, which is like our water in all ways except that it has the chemical structure XYZ, still goes by the name "water." Moreover, on both Earth and Twin Earth, the meaning of "water" when uttered by the denizens of each respective world is determined by the chemical structure of the referent at that world. Thus, if a denizen of Earth were to unwittingly travel to Twin Earth and declare "There's water" when happening upon a clear and refreshing substance, the proposition their utterance expresses would be false. Why? Because the proposition that is water would have as a constituent their concept of water (i.e., with the chemical structure $\mathrm{H}_{2} \mathrm{O}$ ). But what the denizen of Earth has happened upon is not $\mathrm{H}_{2} \mathrm{O}$. It is XYZ. In this way, then, whether or not one can refer to a mind-independent object by means of direct reference depends on one's history of interaction with that object.

The foregoing, then, provides a first strategy for explaining how we might keep theology distinct from philosophy of religion. According to such a strategy, it is possible that just as a denizen of Earth on Twin Earth might not be able to refer (at least for a time) to the object of hydrology on Twin Earth (i.e., XYZ) in virtue of the referent of "water" having been fixed for them to the wrong object (i.e., $\mathrm{H}_{2} \mathrm{O}$ ), so too might a mere philosopher of religion fail to refer to the object of theology since they might have a referent for "God" that is not God. For instance, perhaps they think of "God" deistically and believe that God exists in virtue of their studying the arguments of natural theology. It certainly seems arguable that the operative concept of God for them might not be fixed by direct reference to the God's act of revealing Godself to them, but rather, might amount to no more than an description of a being arrived at through a priori reasoning that, for instance, created the world, set it in motion, and subsequently abandoned it. If so, then such a person does not refer to the object of theology in their claims about what they call "God," in which case they are not capable of doing theology (i.e., in the scientific sense).

While the above strategy provides at least a coherent model which, if correct, would enable us to distinguish theology from mere philosophy of religion, I suggest that the second strategy, to be developed presently, is more promising. Unlike the first strategy, the second allows that non-theologians can refer to the object of theology without any difficulty. Moreover, it allows that non-theologians can even believe and express true propositions about God without any difficulty. Many will think, then, that no more needs to be said, for if we concede that someone can refer to God and believe true proposition about God, then surely that should suffice to conclude that they are capable of doing theology simply in virtue of those two things. The second strategy for distinguishing theology from philosophy of religion, however, argues that a further type of knowledge is necessary if someone is to be a theologian; namely, personal knowledge of God.

This strategy for distinguishing theology from philosophy of religion, like the former one, is best explained by drawing on an analogy; namely, between studying an actual person as distinguished from studying the life of that person. Consider, as an example, the distinction between studying the life of Abraham Lincoln, on the one hand, and studying Abraham Lincoln, on the other. No one living today has access to 
Abraham Lincoln the person in a robust sense. True, they have access to some of Lincoln's writings, but they do not have intimate access to personal knowledge regarding, for instance, what it was like for Lincoln to respond to his notoriously inharmonious cabinet. ${ }^{26}$ Moreover, and relevant to the question of theology where the object of theology is present to all of time (either everlastingly or atemporally), no one living today has personal knowledge of what it is like for them to interact with Abraham Lincoln. Given all of this, then, it seems clear enough that in this day and age we can at best study the life of Abraham Lincoln, for no one has access to a sufficient amount of the personal knowledge required to study Abraham Lincoln. ${ }^{27}$

Our situation relative to people living today, however, is importantly different than our situation relative to Abraham Lincoln. In addition to learning facts about my friends and how they interact with other people, I can know them on a personal level that is not reducible to my propositional knowledge about them. ${ }^{28}$ Once we apply this insight to our earlier case of Katherine, the bona fide theologian with knowledge of the person of God, and Toni, who possesses all and only the propositional knowledge about God that Katherine had, the distinction between theology and mere philosophy of religion emerges.

The suggested analogy, then, is this: the propositional information that Katherine is able to transfer to Toni is alone insufficient for Toni to do more than study the life of God (i.e., facts about the effects and traces of God in the world), for only if Toni himself has the right sort of experience of God by which he can acquire personal knowledge of God can he succeed at the more demanding study of God. And until Toni acquires the relevant relationship to God in virtue of God's revealing Godself to him, he is blocked from studying God in a way which is analogous to the person wishing to study Abraham Lincoln today; that is, both are stuck with no better prospect than to study the propositional history of their respective objects rather than the objects themselves. Thus, if we wish to preserve an objective and firm scientific distinction between the practices of theology and philosophy of religion, the most promising route, according to this strategy, is to single out personal knowledge of God as exclusive and fundamental to the practice of theology.

In this section, I have constructed two different models consistent with the scientific understanding of philosophy of religion and theology which preserve a clear distinction between both disciplines. The success of the first strategy rests on the reasonability of attributing to theologians a privileged ability to refer to God. The second strategy, on the other hand, allows that non-theologians can refer to God unproblematically. However, its success rides on the reasonability of attributing to theologians privileged access to personal knowledge of God that is fundamental to the practice of theology. Before concluding this constructive proposal, then, let us

\footnotetext{
${ }^{26}$ If you want to read up on Lincoln's biography, the following is worth your time: Miller (2002).

27 That is, unless we use this claim in a way that can be translated without loss of meaning to the claim that we are studying the life of Abraham Lincoln

${ }^{28}$ For a defense of the existence of this sort of personal knowledge, see Pinsent (2011).
} 
briefly consider some objections and what motivations there are for preserving the distinction between theology and philosophy of religion in the first place.

\section{Objections and Motivations}

\section{Objection 1: If Atheism is true, then there are no theologians}

If one defines theology as a science in the way suggested above, then if atheism is true, there are no theologians. That is, theology as a science is impossible to practice at any world in which there is no God. Perhaps you think this is a reductio ad absurdum on the position described in this paper. If so, allow me to try and persuade you otherwise.

Consider, for instance, someone who historically studied phlogiston, let us call them Georgiana, and now suppose that rather than define themselves as a chemist, they define themselves as a phlogistonist. Georgiana's reasoning for this is that phlogiston is her primary object of scientific investigation, and so, she thinks her particular scientific practice should be distinguished from the more general science of chemistry. Suppose, finally, that Georgiana is provided with undeniable proof that there is no such thing as phlogiston. Should she maintain a commitment to the claim that she is a phlogistonist?

Suppose Georgiana does continue to claim she is a phlogistonist, and we then ask her to describe the nature of her object of study in light of her new awareness of its non-existence. Here is something Georgiana cannot consistently claim; namely, that there is an object in the world that instantiates the concept of phlogiston. Rather, at best Georgiana can reasonably claim that she has studied the uninstantiated concept of phlogiston, and that such a study is not really scientific in the way the study of real chemical elements and compounds. That is, because phlogiston does not exist, if one were to define the study of phlogiston in terms of some concrete object called phlogiston, then no one could study phlogiston at that world. ${ }^{29}$ This seems precisely right, and surely anyone who had been studying phlogiston and became convinced of its non-existence would have thought that continued attempts to study phlogiston were a waste of time. I suggest, then, that if we define theology as a science involving the study of a concrete personal object, then just as the non-existence of phlogiston prevents the existence of phlogistonists, so the non-existence of God precludes the existence of theologians.

\section{Objection 2: Misidentified Philosophers and Theologians?}

If one defines theology as a science as suggested here, it seems as if there are many scholars who consider themselves philosophers of religion who in fact, perhaps

\footnotetext{
${ }^{29}$ Notice that it does not follow from what I say here that someone who studied phlogiston was not a scientist or scientific in how they went about their work.
} 
unwittingly, are theologians. Someone might worry again that such a result is a reductio ad absurdum on the definition of theology as a science.

On the whole, I think of the above description as a feature rather than a defect in the definition of theology, but it is worth clarifying lest someone misunderstands what I have claimed here. First, if someone is a theologian, then they can also count as a philosopher of religion, for they are engaged in conceptual analysis with the concept of God. Having personal knowledge of God does not preclude one's possessing propositional knowledge about God, so there is simply no reason to think someone who thinks of themselves as a philosopher of religion, despite also being a theologian, is mistaken. Second, constructivist definitions of theology and philosophy (i.e., definitions that are reducible to the preferences and practices of human ways of dividing up disciplines) possess pragmatic value. As a result, I have no wish in this paper to suggest that such constructivist definitions ought to be shunned. Thus, if those who think of themselves as philosophers of religion or theologians do so in virtue of assuming constructivist definitions when dividing up where different scholars fit, that is perfectly fine. If the scientific definitions of philosophy of religion and theology are right, of course, then there will be a mismatch between those counted as philosophers and theologians by one definition when compared with the other definition. But this is not a reason to think one definition is better than another. They are serving different purposes.

\section{Motivation}

And this brings us to an important question: if constructivist and scientific definitions of theology and philosophy of religion serve different purposes, then what purposes served by the scientific definitions under question are sufficiently important that we ought to preserve them in academic discourse? This is, of course, a crucial question.

First, theology is, in this author's view, done best when engaged with the historical tradition, and the definition of theology as a science has been a significant topic in the historic Christian tradition of theology (e.g., see footnote 2). Thus, it is important at least for theology that the scientific definition of theology be retained and developed in light of and in dialogue with contemporary discussions.

Second, if (i) the definition of theology as a science is legitimate, (ii) either of the strategies for distinguishing theology from philosophy of religion in $\S 3$ are correct, and (iii) God exists, then those who count as theologians according to the scientific understanding of theology have epistemic access to knowledge of God that could not be obtained by anyone else. If so, then it would be important to ensure that such persons play at least some role in shaping theological studies in the academy with the hopes of better enabling students to acquire personal knowledge of God (or the ability to refer to God) in addition to acquiring propositional knowledge about God.

Third, the academic study of theology is too often treated as if it can be done well in isolation from religious practices (e.g., liturgy, gathering with one's religious 
community, prayer, etc.). ${ }^{30}$ If, however, theology requires personal knowledge of God (or the ability to refer to God), then religious practices become central to theology. For these reasons, then, it is at least good for us to preserve the scientific definition of theology in academic discourse.

\section{Conclusion}

I have argued, pace Torrance, that both theology and philosophy of religion are a science in his sense, and consequently, cannot be distinguished from each other by denying of one of them the status of a science. However, on the positive side, I have also argued that the distinction between theology and philosophy of religion can be preserved if one attends to features peculiar to the object of theology; namely, that either the object of theology is one to which we can refer only if we bear the right sort of historical relationship or the study of the object requires the possession of knowledge of a person. Thus, although this article is in part a response to Torrance, it is also meant as a work of constructive theology with the aim of amending his provocative definition of theology as a science in order that it might be met with a wider reception; that is, a reception which, as I have argued, it deserves. ${ }^{31}$

\section{References}

Abraham, William J. 2009. "Systematic Theology as Analytic Theology." In Analytic Theology: New Essays in the Philosophy of Theology, edited by Michael C. Rea and Oliver D. Crisp. Oxford University Press: 54-69.

Barth, Karl. 2010. Church Dogmatics. Edited by G.W. Bromily and T.F. Torrance. Hendricksons Publishers.

Bogardus, Tomas and Malorie Urban. 2017. "How to Tell Whether Muslims and Christians Worship the Same God." Faith and Philosophy 34(2): 176-200.

\footnotetext{
30 For very interesting recent work on religious practice, see Wolterstorff (2018) and Cockayne and Salter (2019).

31 I would like to personally thank Andrew Torrance for generous and extensive discussions on this issue and for continually challenging me to think more intentionally about how my scholarship can be more robustly theological. I am also grateful to Joshua Cockayne, Andy Everhart, Kevin Nordby, Stephanie Nordby, Alan Torrance, and Chris Woznicki for helping me work my way through the ideas of this paper on various occasions as well. And lastly, I would like to thank the Templeton Religion Trust whose generous funding created an environment uniquely well-suited for pursuing the ideas of this paper.
} 
Chalmers, David. 1996. The Conscious Mind: In Search of a Fundamental Theory. Oxford University Press.

Cockayne, Joshua and Gideon Salter. 2019. "Praying Together: Corporate Prayer and Shared Situations." Zygon 54(3): 702-730.

Crisp, Oliver D. 2011. "Analytic Theology." The Expository Times 122(10): 469-477. 2019. Analyzing Doctrine. Baylor University Press.

Feldman, Richard. 2003. Epistemology. Prentice Hall.

Fine, Kit. 2005. "Our Knowledge of Mathematical Objects." In Oxford Studies in Epistemology, Vol. 1, edited by Tamar Szabó Gendler and John Hawthorne. Oxford University Press: 89-109.

Goldman, Alvin. 1979. "What is Justified Belief?” In Justification and Knowledge: New Studies in Epistemology, edited by George S. Pappas. Reidel: 1-25.

King, Jeffrey C., Scott Soames, and Jeff Speaks. 2014. New Thinking About Propositions. Oxford University Press.

Kripke, Saul. 1972. Naming and Necessity. Harvard University Press.

Margolis, Eric and Stephen Laurence. Spring 2011. “Concepts.” In The Stanford Encyclopedia of Philosophy, edited by Edward N. Zalta, URL = $<$ https://plato.stanford.edu/entries/concepts/>. Last Accessed June 3, 2019.

McCall, Thomas H. 2015. An Invitation to Analytic Christian Theology. InterVarsity Press Academic.

Merricks, Trenton. 2015. Propositions. Oxford University Press.

Miller, William Lee. 2002. Lincoln's Virtues: An Ethical Biography. Knopf.

Olson, Eric. 1997. The Human Animal: Personal Identity Without Psychology. Oxford University Press.

Pinsent, Andrew. 2011. The Second-Person Perspective in Aquinas' Ethics: Virtues and Gifts. Routledge.

Putnam, Hilary. 1973. “Meaning and Reference.” The Journal of Philosophy 70(19): 699-711.

. 1975. “The Meaning of 'Meaning'." Minnesota Studies in the Philosophy of Science 7: 131-193.

Rea, Michael C. 2009. "Introduction." In Analytic Theology: New Essays in the Philosophy of Theology, edited by Michael C. Rea and Oliver D. Crisp. Oxford University Press: 1-30. 
Rutledge, Jonathan C. 2019. "Analyzing the Muddles of Analysis: (Some of) What Analytic Theology Can Learn from the History of Analytic Feminism." Modern Theology (2019): doi:10.1111/moth.12525.

Schechtman, Marya. 1996. The Constitution of Selves. Cornell University Press.

Shoemaker, Sydney. 2011. "On What We Are." In The Oxford Handbook of the Self, edited by Shaun Gallagher. Oxford University Press: 352-371.

Stump, Eleonore. 2018. Atonement. Oxford University Press.

Timpe, Kevin. 2015. “On Analytic Theology.” Scientia et Fides 3(2): 9-22.

Torrance, Andrew. 2019. "The Possibility of a Scientific Approach to Analytic Theology." Journal of Analytic Theology 7: 178-198.

Torrance, T.F. 1996. Theological Science. T\&T Clark.

Turretin, Frances. [1679-1685] 1847. Institutio of theolgiae elencticae. Edinburgh (originally published in Geneva).

Webster, John. 2015. "What Makes Theology Theological?" Journal of Analytic Theology 3: 17-28.

Williamson, Timothy. 2000. Knowledge and its Limits. Oxford University Press. . 2007. The Philosophy of Philosophy. Blackwell Publishing.

Wolterstorff, Nicholas. 2018. Acting Liturgically: Philosophical Reflections on Religious Practice. Oxford University Press.

Wood, William. 2014. "Analytic Theolog as a Way of Life." Journal of Analytic Theology 2: 43-60.

Zagzebski, Linda Trinkaus. 2012. Epistemic Authority: A Theory of Trust, Authority, and Autonomy in Belief. Oxford University Press.

__ 2018. Exemplarist Moral Theory. Oxford University Press. 